\title{
Translation Procedures Applied in Localized Websites
}

\author{
I Putu Aryadi Jaya, Denpasar, Indonesia \\ Contact Person: 081805444939 \\ aryadijaya87@gmail.com
}

\begin{abstract}
Many companies have their website contents translated into languages spoken by many people globally. Here, translation plays an important role in making people who speak different languages know and understand more about certain products, services, terms and conditions, and also as a part of sales and marketing strategies.

The data in the form of sentences containing terminologies in SL (English) and their translations in TL (Indonesian) were collected from Booking.com and Expedia.co.id using the observation method and the note-taking technique.

The results showed that the types of terminologies analyzed in this study based on the data sources are: 1) power words; 2) hospitality terms; 3) Internet terms; and 4) legal terms. The translation procedures used in translating the selected terminologies vary greatly, namely transference, literal, naturalization, synonymy, couplet, shift, componential analysis, reduction, and expansion.
\end{abstract}

Keywords: terminologies, localization, booking websites

\begin{abstract}
Abstrak
Banyak perusahaan yang menerjemahkan konten situsnya ke dalam bahasa yang digunakan oleh banyak orang secara global. Di sini, penerjemahan memainkan peran penting agar orang yang menggunakan bahasa yang berbeda mengetahui dan memahami lebih banyak tentang produk, layanan, syarat dan ketentuan, dan juga sebagai bagian dari strategi penjualan dan pemasaran.

Penelitian ini bertujuan untuk mengidentifikasi jenis-jenis terminologi umum dan padanan yang digunakan serta menganalisis prosedur penerjemahan yang diterapkan dalam dua situs pemesanan lokal dari Bahasa Inggris ke Bahasa Indonesia. Penelitian ini adalah penelitian kualitatif. Data dalam bentuk kalimat yang mengandung terminologi dalam bahasa sumber (Bahasa Inggris) dan terjemahannya dalam bahasa sasaran (Bahasa Indonesia) dikumpulkan dari Booking.com dan Expedia menggunakan metode observasi dan teknik mencatat.

Hasil penelitian menunjukkan bahwa jenis terminologi yang dianalisis dalam penelitian ini berdasarkan sumber data adalah: 1) kata-kata 'power'; 2) istilah keramahtamahan; 3) istilah Internet; dan 4) istilah hukum. Prosedur penerjemahan yang digunakan dalam menerjemahkan terminologi yang dipilih sangat bervariasi, yaitu peminjaman, literal, naturalisasi, sinonim, couplet, shift, analisis komponen, reduksi, dan ekspansi.
\end{abstract}

Kata kunci: terminologi, pelokalan, situs pemesanan 


\section{Introduction}

The rapid development of information and technology helps people in many ways. In this digital era, more and more businesses create websites, and many of them especially big companies or multinational ones realize the importance of making their website available in more than one language to reach more people and increase their website traffic which will then provide higher possibility to increase their sales. Many companies have their website contents translated into languages spoken by many people globally, or have their website content translated into a local language spoken by people living in a country or region where they build their business branch. Here, translation plays an important role not only in reaching more people who speak different languages to make them know and understand more about certain products, services, terms and conditions, and etc., but also as a part of sales and marketing strategies to increase the sales of the companies concerned.

According to Localization Industry Standard Association (LISA) cited in Pym (2010), localization involves taking a product and making it linguistically and culturally appropriate to the target locale (country/region and language) where it will be used and sold, while internationalization is the process of generalizing a product so that it can handle multiple languages and cultural conventions without the need to redesign. Website localization enables companies to increase their sales since they can reach more people. Website localization does not only bring advantages both for the business owner and the local customers, but it also provides job opportunities for translators and localizers. It increases the demands for translation service and "the localization industry may benefit from the enhanced knowledge of translation theory" (Pym, 2006).

The variety of website contents ranging from static content, such as company profile, terms and conditions up to dynamic content such as new product or service descriptions, requires a wide range of knowledge and skills, for example, terms and conditions may contain legal terms, while product or service descriptions usually contain persuasive language.

Another challenge in website localization that may be encountered by translators is the internet terminologies the equivalent of which can barely be found in the local language such as the internet term 'cookie'. Some linguists in the target language, in this case the Indonesian language, have coined a new term as an equivalent of this word, i.e. ' $k u k i$ '. However, this may not be widely known by people as it is in the process of entering common usage. The decision now lies in the hands of the translators whether to borrow the term 'cookie', or use a newly coined term 'kuki'.

Other examples of the internet terminologies that may pose a similar challenge to the translators are, among others, the terms 'upload' and 'download' that may be translated into 'unggah' and 'unduh'; 'copy' and 'paste' that may be translated into 'salin' and 'rekat'; and 'email' that may be translated into 'surel' that stands for 'surat elektronik'; and the term 'disclaimer' that can be translated into 'penafian'. Many Indonesian people have already been accustomed to using 'copy and paste', 'email' and 'disclaimer' and many prefer to borrow or use those terms. However, some linguists think that it necessary to coin new words in the target language (a neologism), or to use the nearest possible equivalent in the target language to promote the use of the target language terms instead of borrowing the words from the source language.

Looking at the challenges and interesting phenomena in localization, this study aims to identify the types of common terminologies and the equivalents used, and analyze the translation procedures applied in the two localized booking websites from English into Indonesian.

The data sources are Booking.com and Expedia.co.id. These websites are two among some of the world leading online booking 
websites. The website contents of these two websites are made available in more than 30 languages, including the Indonesian language.

Some terminologies in these websites that may be found interesting to be discussed were selected and used as data. Their translations in the Indonesian language were also used as data. Comparing the translation and the translation procedures used in the two different websites is beneficial. In addition to investigating the types of translation procedures applied, this study also analyzes the possible effects of the translation procedure applied, by implementing some relevant theories in the translation field. Hopefully, this study can serve as a useful reference for localizers, translators and anyone interested in the translation study.

\section{Research Method}

In conducting research, an appropriate methodology plays an important role. This chapter deals with the research approach, data source, the method and technique of collecting data, the method and technique of analyzing data, and the method and technique of presenting the analyzed data.

\section{Research Approach}

This study applies qualitative research approach. The data analyzed in this study are in the form of sentences containing selected terminologies collected from two localized websites, namely Booking.com and Expedia.co.id. The qualitative observation method was applied, and the results of the analysis were presented using descriptive sentences, tables and images or screenshots where necessary.

\section{Data Source}

The data were collected from Booking.com and Expedia.co.id. They are among some of the world leading online booking websites. The website contents of these two websites are made available in more than 30 languages, including the Indonesian language. The data are divided into two, namely the English text (the source language) and the Indonesian text (the translation).

\section{Method and Technique of Collecting Data}

Before collecting data, understanding the concept of website localization and types of translation procedures is very important. As this study is library research, the first step in the process of collecting data was a thorough observation of the two localized websites, namely Booking.com and Expedia.co.id., and the text in SL and TL using the observation method. Newmark's typology of translation procedures (1988) was implemented at this stage. The notetaking technique was applied where necessary to support the process of identifying and classifying the data.

Texts containing interesting terminologies from the websites were collected. First, the sentences containing interesting terminologies were highlighted. Next, some sentences which were considered representative were then used as data for analysis. The selected data were numbered, arranged and presented in tables to be further analyzed in the following process that is the process of analyzing data.

\section{Method and Technique of Analyzing Data}

The method of analyzing data applied in this study is the qualitative method. The analysis is presented in descriptive sentences. The data were grouped based on the types of terminologies, and then the translation procedures used were analyzed.

The translation procedures were identified using the theory on translation procedures proposed by Newmark (1988), and the analysis was supported by the theory on website localization by Pym (2010), Peter Sandrini (2005 and 2007), Esselink (2000) and other related theories. 


\section{Method and Technique of Presenting the Analyzed Data}

This study applied two methods in presenting the analyzed data, namely the informal method and the formal method as proposed by Sudaryanto (1993). He states that there are two methods of presenting the analyzed data; they are informal and formal methods. The informal method refers to the method of presenting the analyzed data in descriptive words, meaning that the findings can be described in words, natural language, while the formal one refers to the presentation of the analyzed data using symbols, diagrams, figures, and tables. The data are grouped and presented in tables, while the results of the analysis are explained using descriptive sentences.

\section{Discussion \\ Types of Terminologies Used in Booking.com and Expedia.co.id}

Like other websites in general, Booking.com and Expedia.co.id. consist of static pages and dynamic pages. Static pages are not updated on a daily basis since the information on these static pages is not frequently changed. In contrast, dynamic pages are updated frequently. There is also another term called 'landing pages' on which we will land at the first place when we click on their website. Normally, the landing page is a home page which is usually a dynamic page. Home page is a website primary page. Campbell (2014: 79) says that the home page is the anchor for the entire website, and the underlying pages provide detailed content and interest. Website visitors will access underlying pages using the navigation tools that the website provides, a search box, or links from the home page or landing page. In addition to that, a home page should indicate clearly who owns or publishes the website, what visitors can expect to find at the website, why they should visit this particular website, and where specific information or website features are located. In these two websites, the landing page or the
'Home' page contains information, such as rates, featured destinations and articles, and top or best deals of today.

In addition to having a home page which is a dynamic page, Booking.com and Expedia.co.id. also have some static pages, among others the 'About Us', 'Terms of Use' and 'Privacy Statement' pages. The 'About Us', 'Terms of Use' and 'Privacy Statement' pages are all the underlying pages in the two websites. The 'About Us' page in both websites contains a brief description of the company, which includes the year of establishment, and the points that make the company stand out among the companies of the same line of business. The 'About Us' page on Booking.com is entitled 'About Booking.com'. Meanwhile, the 'Terms of Use' page in these two websites is entitled differently. Booking.com uses 'Trip Terms and Conditions' while Expedia.co.id uses 'Website Terms of Use'. This type of page contains information on the scope of the company's business, the use of the website, activities that are prohibited, prices, rules, privacy policy, reviews, hotel reservations, copyright, and disclaimer. Meanwhile, the 'Privacy Statement' page is about how the companies use and process the users' personal data. Booking.com uses 'Privacy Statement', while Expedia.com uses 'Privacy Policy.

The pages analyzed in this study are limited to the 'Home', About Us', 'Terms of Use' and 'Privacy Statement' pages. Many business websites have these types of pages, and this is the reason why these pages were selected to be analyzed in this study. These pages are considered sufficient to provide data on static and dynamic parts of the websites. The contents of these pages were collected on 8 December 2018. Some common terminologies present in those pages, in the form of words, phrases and sentences, were identified, selected, collected, and then classified.

It appears that there are four (4) types of terminologies found. They are power words, 
terminologies related to hospitality, internet terminologies and legal terminologies.

\section{Power Words}

Power words are persuasive words used by marketers to trigger an emotional response to get a visitor to click, share, or buy a product or service. These power words are usually found on the landing page, in this case, the home page of the two websites. As stated earlier, a landing page is the first page that visitors will encounter when visiting a website. Marketers or businesses make use of this fact by placing their power words to persuade their website visitors to buy or use the products or services they offer or simply to take actions. These words invoke emotions and trigger curiosity.

The power words found in the two websites are in the forms of single words, noun phrases, imperative sentences and questions.

\section{Hospitality Terms}

Hospitality terms are the terms commonly used in the tourism industry. The hospitality terms analyzed in this study were mostly collected from the homepage of the two websites.

\section{Internet Terms}

Internet terms are words or phrases related to the Internet. The advanced development of technology gives rise to the increasing number of new terminologies, among others, Internet terminologies. The Internet terminologies analyzed in this study were collected from the terms of use and privacy statement or privacy policy of the two websites.

\section{Legal Terms}

Legal terms are words or phrases used in legal context. Legal terms are commonly found on a website terms of use page. There is a considerable number of legal terminologies found in the two websites. They include archaic adverbials, doublets, and triplets.
Translation Procedures Used to Translate the Selected Terminologies found in Booking.com and Expedia.co.id

It is interesting to see the translation procedures used in the four categories of terminologies in this study. The analysis on the translation procedures used in the two websites is presented based on the categories of the data.

\section{Translation Procedures Used in Translating Power Words}

All of the selected data in this category were collected from the home page of the two websites. They are in the form of single words, phrases, imperatives, and questions. The data chosen were not only in the form of a single word, but also other grammatical units, such as phrases, clauses and sentences to provide a more comprehensive look at the challenges faced by translators in translating the contents provided in a website homepage. After identifying the translation procedures used in translating the selected power words in the selected data into Indonesian, it can be stated that the procedures used vary. The most used procedure is literal translation.

Table 1 - The Use of Literal Procedure in Translating Power Words

\begin{tabular}{|c|c|c|}
\hline $\begin{array}{l}\text { SLT } \\
\text { (English) }\end{array}$ & $\begin{array}{l}\text { TLT } \\
\text { (Indonesian) }\end{array}$ & $\begin{array}{l}\text { Translation } \\
\text { Procedure }\end{array}$ \\
\hline $\begin{array}{l}\frac{\text { Save }}{\text { save }} \\
\text { money! (B) }\end{array}$ & $\begin{array}{l}\text { Hemat } \\
\underline{\text { hemat }} \text { uang! }\end{array}$ & Literal \\
\hline $\begin{array}{l}\text { Stay Longer } \\
\& \text { Save }(\mathrm{E})\end{array}$ & $\begin{array}{lr}\text { Menginap } & \text { lebih } \\
\text { lama } & \& \\
\text { Berhemat } & \\
\end{array}$ & Literal \\
\hline $\begin{array}{l}\text { Register } \\
\text { (B) }\end{array}$ & $\overline{D a f t a r}$ & Literal \\
\hline
\end{tabular}

The word 'save' was well translated into 'hemat' and likewise, the word 'save' was also properly translated into 'berhemat'. There are actually 
some translations of the word 'hemat' in Indonesian, depending on the context. Here, the translator has appropriately translated the word 'save' into 'hemat' and 'berhemat' without losing the power of the word in the source text. Likewise, 'register' was also accurately translated into 'daftar'. Both of these power words are used in the form of 'the base form of verb (the infinitive)' or imperatives.

\section{Translation Procedures Used in Translating Hospitality Terms}

There selected data represent the hospitality terms used in the two websites. Most of the selected data in this category were collected from the home page of the two websites. Some were collected from the other three web pages. Most of the data in this category are in the form of single words and some are in the form of phrases. The translation procedure mostly used in translating the hospitality terms is naturalization.

Table 2 - The Use of Naturalization in Translating Hospitality Terms

\begin{tabular}{|c|c|c|}
\hline $\begin{array}{l}\text { SLT } \\
\text { (English) }\end{array}$ & $\begin{array}{l}\text { TLT } \\
\text { (Indonesian) }\end{array}$ & $\begin{array}{l}\text { Translation } \\
\text { Procedure }\end{array}$ \\
\hline $\begin{array}{l}\text { Destination } \\
(\mathrm{B}, \mathrm{E})\end{array}$ & Destinasi & Naturalization \\
\hline $\begin{array}{l}\text { No } \\
\text { reservation } \\
\text { fees (B) }\end{array}$ & $\begin{array}{l}\text { Tanpa biaya } \\
\text { reservasi }\end{array}$ & Naturalization \\
\hline $\begin{array}{l}\text { List your } \\
\text { property (B) }\end{array}$ & $\begin{array}{l}\text { Daftarkan } \\
\text { properti }\end{array}$ & Naturalization \\
\hline $\begin{array}{l}\text { Add your } \\
\text { property (E) }\end{array}$ & $\begin{array}{l}\text { Anda } \\
\text { Tambahkan } \\
\text { properti } \\
\text { Anda }\end{array}$ & Naturalization \\
\hline $\begin{array}{l}\text { Relaxation } \\
\text { (B) }\end{array}$ & Relaksasi & Naturalization \\
\hline $\begin{array}{l}\text { Hotels (B, } \\
\text { E) }\end{array}$ & Hotel & Naturalization \\
\hline Hostels (B) & Hostel & Naturalization \\
\hline $\begin{array}{l}\text { Accommo- } \\
\text { dation (B, }\end{array}$ & Akomodasi & Naturalization \\
\hline
\end{tabular}

\begin{tabular}{lll}
\hline E) & & \\
Apartments & Apartemen & Naturalization \\
(B) & & \\
Villa (B) & Vila & Naturalization \\
Resort (B) & Resor & Naturalization \\
\hline
\end{tabular}

The word 'destination', the word 'reservation', the word 'relaxation', and the word 'accomodation' all carry the derivational suffix ion. This derivational suffix was replaced by 'si' in the TLT, thus making the naturalized form of these words become respectively 'destinasi', 'reservasi', 'relaksasi' and 'akomodasi'. As for the naturalization of the word 'relaxation', in addition to the change of the derivational suffix ion into -si, the $/ \mathrm{x} /$ is also changed into $/ \mathrm{ks} /$, thus making it 'relaksasi'. Meanwhile, as for the naturalization of the word 'accommodation', apart from the change of the derivational suffix ion into -si in TLT, the consonant /cc/ is also changed into $/ \mathrm{k} /$ as this kind of double consonant does not exist in the Indonesian language, and $/ \mathrm{mm} /$ does not either, one of $/ \mathrm{m} /$ of which is dropped.

'Hotel' is one of the most common terms used in booking websites. The word 'hotel' means 'a building where people pay to stay and eat meals' (Longman Dictionary of Contemporary English Online, 2019). The TL readers are already familiar with this term as it is already listed in the Dictionary of the Indonesian Language (KBBI). Here, the word 'hotels', was translated using the naturalization procedure by dropping the inflectional suffix -s following the Indonesian language system. In English, most nouns are inflected for number with the inflectional plural affix -s (as in "dog" $\rightarrow$ "dog-s"). In Indonesian, however, this plural system does not exist, so the word 'hotel' does not have the ending's' here. To indicate that the noun is plural, reduplication (such as 'hotel-hotel') is used. Alternatively, a marker of the plural form in the Indonesian language such as, among others, an adjective 'banyak' which means 'many', 'sedikit' meaning 'a few' or 'some' or 'a little' is used. However, 
Vol. 26. No 2

this does not always work that way. It will depend on the context, for example, in translating a word on a homepage which leads to a link, it is important to keep in mind the element of brevity. This is also the case with the word 'hostels', which was translated into 'hostel'.

The word 'apartments' was translated into 'apartemen' where the letter ' $t$ ' that comes after the consonant ' $n$ ' was dropped in the TL, so was the inflectional suffix -s. In addition to that, the vowel ' $e$ ' was added after the consonant' $t$ ', making the STL become 'apartemen'. Meanwhile, the word 'villa' was translated into 'vila' by dropping one of the letter ' 1 '.

Meanwhile, the word 'property' was naturalized into 'properti' by changing the phoneme -y at the end of the word into -i. Lastly, the word 'resort' was translated into 'resor' which actually means 'a small area' (KBBI, 2019) in the TLT. So far, there has not been any concise equivalent of the word 'resort' and thus, it is better to use the transference procedure when translating this word. Again, translators need to bear in mind that consulting dictionary both for words in SLT and TLT is equally important to make sure that translation is accurate and acceptable.

\section{Translation Procedures Used in Translating Internet Terms}

The selected data which represent the Internet terms were used in the two websites. Most of the selected data in this category were collected from the terms of use and privacy statement or privacy policy of the two websites. All of the data in this category are in the form of single words. The most used procedure is transference.

\section{Table 3 - The Use of Transference in Translating Internet Terms}

\begin{tabular}{lll}
\hline SLT (English) & $\begin{array}{l}\text { TLT } \\
\text { (Indonesian) }\end{array}$ & $\begin{array}{l}\text { Translation } \\
\text { Procedure }\end{array}$ \\
\hline $\begin{array}{l}\text { These terms } \\
\text { and }\end{array}$ & $\begin{array}{l}\text { Syarat dan } \\
\text { ketentuan ini, }\end{array}$ & Transference \\
\end{tabular}

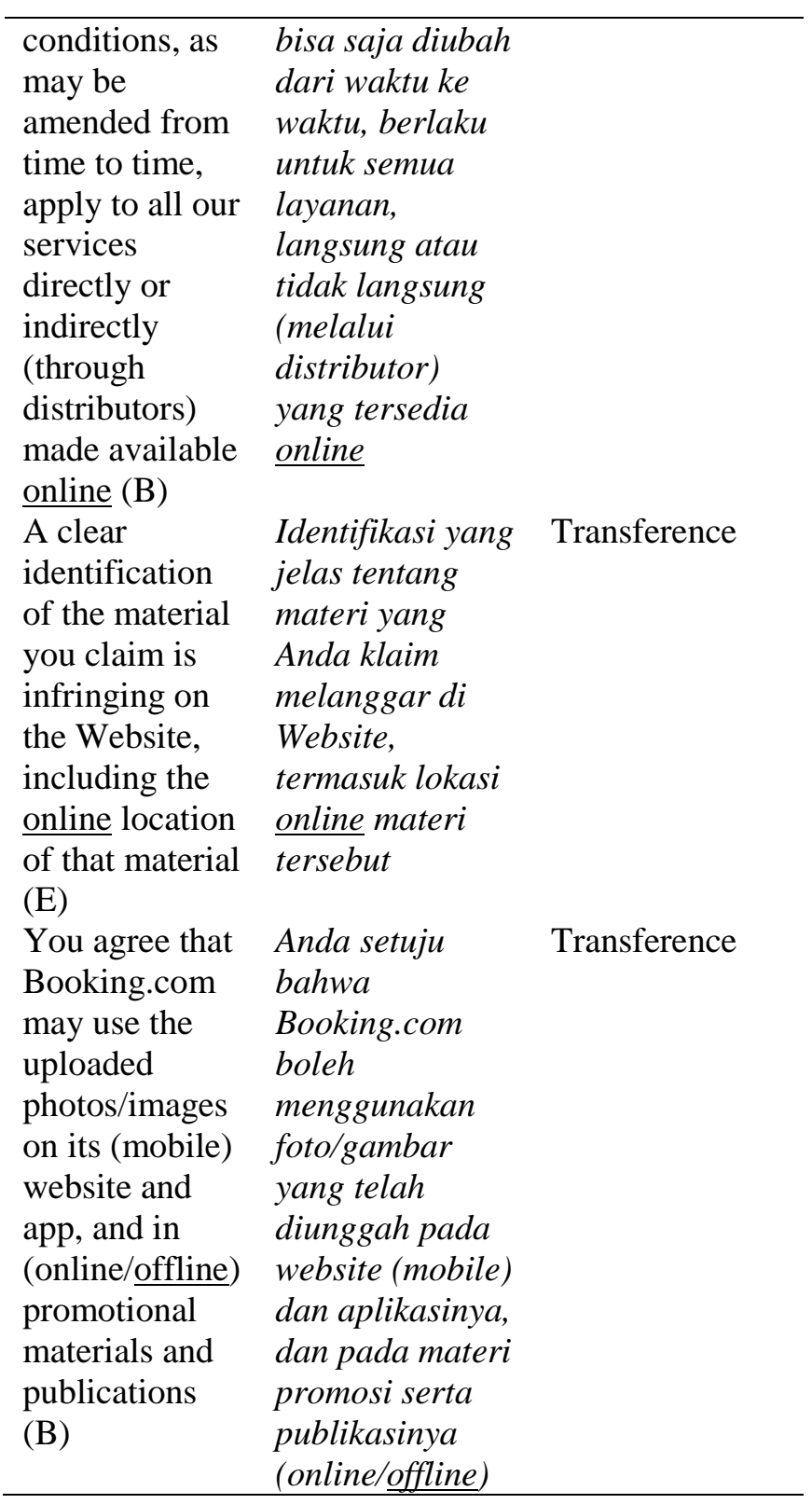

The word 'online' means 'connected to other computers through the Internet, or available through the Internet' (Longman Dictionary of Contemporary English Online, 2019).

It is clear that the procedure applied is the transference procedure. In the beginning of the development of the Internet, certainly there were many words which did not have their equivalents in the Indonesian language including 'online' and 'offline'. These two words were not even listed in the official list of computer terms and their 
equivalents in Indonesian (Panduan Pembakuan Istilah Pelaksanaan Instruksi Presiden Nomor 2 Tahun 2001 tentang Penggunaan Komputer dengan Aplikasi Komputer Berbahasa Indonesia. Kiat Pembakuan Peristilahan Perkomputeran dalam Bahasa Indonesia (Guide to Standardization of Terms as Implementation of Presidential Instruction Number 2 of 2001 on the Use of Computers with Indonesian Language Computer Applications. Tips for Standardizing Computer Terminologies in Indonesian)). This is likely to be the reason why the translators of the two websites chose to apply the transference procedure.

However, it is important to note that there have been newly-coined equivalents for the word 'online', namely 'daring' (dalam jaringan), terhubung, tersambung where in this context among these three choices the most possible one is 'daring' which means 'dalam jaringan' (lit. within the network). These newly coined equivalents were proposed by linguists and language enthusiasts who are eager to promote the use of the Indonesian language in cases where equivalents in the Indonesian language are available. This can be seen in Daftar Istilah Internet Indonesia (List of Internet Terms in Indonesian) available on Wikipedia at this URL with the most recent update on 29 February 2019 (as per the time this analysis is written on 19 May 2019). This word has also been used in the Indonesian Dictionary KBBI as in KBBI Daring, which means KBBI Online.

Similarly, the word 'offline' was transferred into the target language.

The word 'offline' means "not connected to the Internet." The translator of Booking.com prefers to use the transference procedure to translate the term 'offline.' Like the word 'online', the word 'offline' has its equivalents in the Indonesian language, which is 'luring' (luar jaringan)' meaning 'outside the network', tidak terhubung' meaning 'not connected to the network', and 'terputus' meaning 'disconnected' whereby the word 'luring' which stands for 'luar jaringan' is the most suitable in this context. This term has been listed in the KBBI Kemendikbud (Indonesian Dictionary Online developed by the Ministry of Education and Culture).

\section{Translation Procedures Used in Translating Legal Terms}

Most of the selected data in this category were collected from the 'terms of use' page of the two websites. Most of the data in this category are in the form of single words, while some are in the form of phrases, such as duplets and triplets as one of the characteristics of legal text. The most used procedure is literal translation.

Table 4 - The Use of Literal Procedure in Translating Legal Terms

\begin{tabular}{lll}
\hline $\begin{array}{l}\text { SLT } \\
\text { (English) }\end{array}$ & $\begin{array}{l}\text { TLT } \\
\text { (Indonesian) }\end{array}$ & $\begin{array}{l}\text { Translation } \\
\text { Procedure }\end{array}$ \\
\hline The AAE & Perusahaan & Literal \\
Companies & AAE dan & \\
and AAE & Mitra AAE & \\
Partners shall & berhak \\
be entitled to & menegakkan \\
enforce the & penafian dan \\
disclaimers & pembatasan \\
and tanggung \\
limitations of & jawab yang \\
liability set & diatur di \\
out in the & dalam \\
Agreement & Perjanjian \\
\hline
\end{tabular}

In the data, the word 'disclaimer' was translated literally into 'penafian'. The word disclaimer means 'a statement that you are not responsible for or involved with something, or that you do not know about it - used especially in advertising or legal agreements' (Longman Dictionary of Contemporary English, 2019).

Actually, the word 'disclaimer' is more known than the word 'penafian'. Many Indonesian people know 'disclaimer' better than 'penafian' although the word 'penafian' has existed in the 
Indonesian dictionary. It may not be as popular as the word 'disclaimer'. Here, linguists including translators play an important role to popularize the use of less known words like 'penafian' which may look like a newly coined term to some native speakers of Indonesian. Instead of borrowing the word 'disclaimer' using the transference procedure, the translator chose to use the literal procedure to translate this word. This also shows the effort made by the translator to make more people familiar with the word 'penafian'.

\section{Conclusion}

After analyzing the data collected from the two websites analyzed in this study, namely Booking.com and Expedia.co.id, there are two conclusions drawn based on the three formulated research problems. First, the types of text analyzed in this study based on the data sources are: 1) power words; 2) hospitality terms; 3) Internet terms; and 4) legal terms. Most of the data are in the form of single words; some are in the form of phrases; while there are a few of them are in the form of clauses or short imperative sentences and one in the form of a question. These different types of data forms were intentionally selected to enrich the analysis. Secondly, the most used translation procedure in translating the power words into Indonesian is literal translation. Meanwhile, the naturalization procedure being the most applied one in translating the hospitality terms contained in the selected data. It seems that there are quite many hospitality terms that have been absorbed or naturalized in the Indonesian language.

As for the category of Internet terms, the translation procedure of transference is the most used one. There is an interesting issue with the use of newly-coined equivalents in translating some Internet terms that may cause some dilemma on the part of the translators whether to use newly-coined equivalents with a possible consequence, i.e. some readers may not be familiar with them, or to borrow or transfer the
SL terms. Meanwhile, the most used used procedure in translating the selected legal terms in the data is the literal procedure. This is due to the fact that legal translation should be faithful.

\section{Bibliography}

Biber, et al. 1999. Longman Grammar of Spoken and Written English. London: Longman.

Catford, J.C. 1965. A Linguistic Theory of Translation. Oxford: Oxford University Press.

Costales, Alberto F. 2009. "Translation 2.0. The localization of institutional websites under the scope of functionalist approaches". Dries DE CROM (ed.). Translation and the (Trans)formation of Identities. Selected Papers of the CETRA Research Seminar in Translation Studies 2008.

Esselink, Bert. 2000. A Practical Guide to Localization. Amsterdam: John Benjamins.

Guide to Standardization of Terms as Implementation of Presidential Instruction Number 2 of 2001 on the Use of Computers with Indonesian Language Computer Applications. Tips for Standardizing Computer Terminologies in Indonesian (Panduan Pembakuan Istilah Pelaksanaan Instruksi Presiden Nomor 2 Tahun 2001 tentang Penggunaan Komputer dengan Aplikasi Komputer Berbahasa Indonesia. Kiat Pembakuan Peristilahan Perkomputeran dalam Bahasa Indonesia)

Huddleston, Rodney and Geoffrey K. Pullum. 2002. The Cambridge Grammar of the English language. Cambridge: Cambridge University Press.

Jakobson, Roman. 2000. "On Linguistic Aspects of Translation". reprinted in L. Venuti (ed). 2000. The Translation Studies Reader. London and New York: Routledge.

Konecny, David. 2006. "Challenges in Localizing the Masaryk University Information System and Websites" (thesis). Czech Republic: Masaryk University 
Kridalaksana, Harimurti. 1993. Катиs Linguistik. Jakarta: Gramedia.

List of Loanwords in Indonesian, Wikipedia, visited on 19 May 2019, available at the following URL: https://en.wikipedia.org/wiki/List_of_loan words_in_Indonesian

Longman Dictionary of Contemporary English Online. URL: https://www.ldoceonline.com/

Nauert, Sandra. 2007. "Translating Websites". Paper presented at the MuTra Conference 'LSP Translation Scenarios', 30 April - 4 May 2007, Vienna (published in the Proceedings 2007).

Newmark, Peter. 1998. A Text Book of Translation. London: Prentice-Hall.

Nida, Eugane A, and Charles R. Taber. 1964. The Theory and Practice of Translation. Leiden: The United Bible Societies.

Pym, Anthony. 2010. Exploring Translation Theories. New York: Routledge

Quirk, et al. 1985. A Comprehensive Grammar of the English Language. London: Longman

Sandrini, Peter. 2005: "Website Localization and Translation". Paper presented at the MuTra Conference 'Challenges of Multidimensional Translation', (published in the Proceedings 2005).

Sandrini, Peter. 2008. Localization and Translation. In: MuTra Journal, Vol 2 2008. LSP Translation Scenarios. Selected Contributions to the EU Marie Curie Conference Vienna 2007. Edited by Heidrun Gerzymisch-Arbogast, Gerhard Budin, Gertrud Hofer. Saarbrücken: ATRC 167-191.

Sneddon, James Neil. 1996. Indonesian Reference Grammar. Australia: Allen and Unwin Pty. Ltd.

Suasti. 2005. "Indonesian Labour Terms and Their Translation into English" (tesis). Denpasar: Universitas Udayana
Venuty, Lawrance (ed). 2000. The Translation Studies Reader. London and New York: Routledge. 